\title{
Extra Corporeal Membrane Oxygenation (ECMO) in three HIV-positive patients with acute respiratory distress syndrome
}

\author{
Francesco Giuseppe De Rosa ${ }^{{ }^{* \dagger}}$, Vito Fanelli ${ }^{2 \dagger}$, Silvia Corcione ${ }^{1}$, Rosario Urbino ${ }^{2}$, Chiara Bonetto ${ }^{2}$, Davide Ricci ${ }^{3}$, \\ Mauro Rinaldi ${ }^{3}$, Giovanni Di Perri ${ }^{1}$, Stefano Bonora ${ }^{1}$ and Marco V Ranieri ${ }^{2}$
}

\begin{abstract}
Background: Extracorporeal membrane oxygenation (ECMO) is a life-saving bridging procedure in patients with severe acute respiratory distress syndrome (ARDS). Official indications for ECMO are unclear for immunocompromised and HIV-positive patients affected by severe hypoxemia. Uncertainties are related to prognosis and efficacy of treatment of the underlying disease. However, the care of patients with HIV infection has advanced since the introduction of highly active antiretroviral therapy (HAART), with increased life expectancy and decreased mortality.

Case presentation: Three HIV-infected patients with AIDS were admitted to ICU and were treated with ECMO: a 21 years old Caucasian female with congenital HIV infection presented with Pneumocystis jirovecii pneumonia (PJP); a 38 years old Caucasian female with HIV-HCV infection and L. pneumophila pneumonia; a 24 years old Caucasian male with fever, cough weight loss and PJP pneumonia. Two patients were alive, with a good immunovirological profile and they went back to their previous quality of life. The last patient died with septic shock after three months of ICU stay.

Conclusion: ECMO was effective in three HIV-positive patients with an otherwise fatal respiratory failure. All patients had severe immunosuppression and/or limited antiretroviral options. A multidisciplinary critical team is needed to individualize the use of ECMO in immunocompromised patients, including those with HIV infection.
\end{abstract}

Keywords: ECMO, HIV, AIDS, HAART, ARDS, Pneumonia, PJP, Legionella, Immunocompromised patients

\section{Background}

Extracorporeal membrane oxygenation (ECMO) is a feasible life-saving support therapy for patients with severe acute respiratory distress syndrome (ARDS) that is refractory to conventional mechanical ventilation (MV) $[1,2]$. Key factors for the indication of ECMO are represented by prognosis of the underlying disease, timing, quality of life of survivors and the possibility of being lung transplant candidate [2].

Occurrence of ARDS in immunocompromised HIVpositive in HIV-positive patients is associated to an extremely high mortality especially before the introduction of highly active antiretroviral treatment (HAART)
[3]. Under these circumstances, ECMO is usually not recommended in immunocompromised HIV-positive patients that develop ARDS [2,3]. However, nowadays, HIV-positive patients have variable levels of immune function (T-CD4+ lymphocytes/microL) or viral suppression (levels of plasma HIV-RNA) and ARDS may be due to opportunistic infections in antiretroviral-naïve patients or to a bacterial pneumonia during HAART, with considerable differences on the definition of immunocompromised status [3].

We report three cases of successful ECMO support in patients with HIV infection and pneumonia by Pneumocystis jirovecii (two cases) and Legionella pneumophila.

\section{Cases presentation}

The first patient (female, 21 years old, BMI $15.6 \mathrm{Kg} / \mathrm{m}^{2}$, PBW 52.4 kg) had a congenital HIV infection and presented with Pneumocystis jirovecii pneumonia (PJP) after
* Correspondence: $\mathrm{fr}$
${ }^{\dagger}$ Equal contributors

${ }^{1}$ Department of Medical Sciences, University of Turin, Infectious Diseases at Amedeo di Savoia Hospital, Corso Svizzera 164, 10149 Turin, Italy

Full list of author information is available at the end of the article 
Table 1 Main clinical characteristics of patients

\begin{tabular}{|c|c|c|c|}
\hline & Patient 1 & Patient 2 & Patient 3 \\
\hline & Perinatally acquired HIV infection & Previous IDU with HIV-HCV infection & Newly diagnosed HIV infection \\
\hline Diagnosis at admission & $\begin{array}{l}\text { PJP pneumonia after HAART } \\
\text { discontinuation }\end{array}$ & Legionella pneumophila pneumonia & PJP pneumonia \\
\hline HAART & $\begin{array}{l}\text { On HAART for } 21 \text { years, multiple } \\
\text { changes; low compliance }\end{array}$ & Compliant, multiple changes & NA \\
\hline Last HAART & $\begin{array}{l}\text { Darunavir/ritonavir, etravirine, } \\
\text { enfuvirtide and raltegravir: } \\
\text { spontaneously stopped in } 2010 .\end{array}$ & $\begin{array}{l}\text { Tenofovir, lamivudine, darunavir/ } \\
\text { ritonavir }\end{array}$ & $\begin{array}{l}\text { Started on } 18 \text { August: Emtricitabine/ } \\
\text { tenofovir, darunavir/ritonavir, raltegravir, } \\
\text { maraviroc }\end{array}$ \\
\hline $\begin{array}{l}\text { HIV-RNA \& CD4/mm3 at } \\
\text { admission }\end{array}$ & $\begin{array}{l}\text { (HIV-RNA } 386 \mathrm{cp} / \mathrm{ml} ; \text { T-CD4+ } \\
196 \mathrm{cell} / \mathrm{s} / \mathrm{mm}^{3} \text { ), HIV-RNA: } \\
118.330 \mathrm{cp} / \mathrm{ml}^{\prime} \text {; CD4: 2/mm }\end{array}$ & $\begin{array}{l}\text { (HIV-RNA suppressed; T-CD4+ } \\
200 \mathrm{cell} / \mathrm{mm}^{3} \text { ), HIV-RNA: } 500 \mathrm{cp} / \mathrm{ml} \\
\text { CD4: } 170 / \mathrm{mm}^{3}\end{array}$ & HIV-RNA: $50728 \mathrm{cp} / \mathrm{ml} ; \mathrm{CD} 4: 3 / \mathrm{mm}^{3}$ \\
\hline ICU length of stay (days) & 35 & 22 & 81 \\
\hline ECMO duration (days) & 20 & 13 & 24 \\
\hline \multirow[t]{3}{*}{$\begin{array}{l}\text { Antibiotic and antifungal } \\
\text { treatment during ECMO }\end{array}$} & $\begin{array}{l}\text { Cotrimoxazole } 5 \text { mg/kg q8h*; } \\
\text { fluconazole } 200 \text { mg; meropenem } \\
1 \mathrm{gr} \text { q8h. }\end{array}$ & $\begin{array}{l}\text { Cotrimoxazole } 5 \text { mg/kg q8h*; } \\
\text { levofloxacin } 500 \text { mg q12h; rifampin } \\
600 \text { mg/die; pip/tazobactam 4,5 gr } \\
\text { q6h; fluconazole } 400 \text { mg/die. }\end{array}$ & $\begin{array}{l}\text { Cotrimoxazole } 5 \text { mg/kg q8h*; } \\
\text { vancomycin } 1 \mathrm{gr} \text { q24h;metronidazole } \\
250 \mathrm{mg} \text { q8h. }\end{array}$ \\
\hline & $\begin{array}{l}\text { On day } 2 \text { after ECMO changed to: } \\
\text { vancomycin } 750 \mathrm{gr} \text { bid, levofloxacin } \\
750 \mathrm{mg} / \mathrm{die} \text {, piperacillin/tazobactam } \\
4,5 \mathrm{mg} \text { q6h, caspofungin } 50 \mathrm{mg} / \mathrm{die} \\
\text { (with loading dose of } 70 \mathrm{mg} / \mathrm{die} \text {, } \\
\text { clindamycin } 600 \mathrm{mg} \text { q6h and } \\
\text { primaquine per os ganciclovir } 250 \mathrm{mg} \\
\text { bid, due to concern for reduced plasma } \\
\text { concentrations of cotrimoxazole }\end{array}$ & & $\begin{array}{l}\text { On day } 10 \text { after ECMO changed to: } \\
\text { clindamycin } 600 \mathrm{mg} \text { q6h; caspofungin } \\
50 \mathrm{mg} / \mathrm{die} \text { (with loading dose of } \\
70 \mathrm{mg} / \mathrm{die} \text { ); primaquine per os; colistin } \\
9 \mathrm{MU} \text { followed by } 4.5 \mathrm{MU} \text { bid; } \\
\text { meropenem } 2 \mathrm{gr} \text { tid; liposomal } \\
\text { amphotericin B } 150 \mathrm{mg} \text {; atovaquone } \\
750 \mathrm{mg} \text { q6h }\end{array}$ \\
\hline & $\begin{array}{l}\text { After cotrimoxazole switch to } \\
\text { clyndamicin, primaquine and } \\
\text { caspofungin there was a slow } \\
\text { improvement of respiratory function } \\
\text { and ECMO was removed. }\end{array}$ & & $\begin{array}{l}\text { After cotrimoxazole switch to } \\
\text { clyndamicin, primaquine and } \\
\text { caspofungin there was an } \\
\text { improvement of general conditions } \\
\text { and ECMO was removed. }\end{array}$ \\
\hline HAART & $\begin{array}{l}\text { Restarted with tenofovir/emtricitabine, } \\
\text { raltegravir, darunavir / ritonavir, } \\
\text { enfuvirtide and maraviroc }\end{array}$ & As above & As above \\
\hline
\end{tabular}

$\mathrm{cp}=$ copies; ${ }^{*}$ dose based on trimethoprim component.

a 2-year HAART discontinuation (Table 1). This patient was admitted to the emergency ward with fever, cough, dyspnea and weight loss. Chest CT scan showed diffuse and bilateral ground glass opacities. $P$. jirovecii (PJP) was identified by immunofluorescence (IF), performed on bronchoalveolar lavage (BAL) and other virus, bacterial and fungal infections were excluded with appropriate microscopic, cultural or molecular methods on BAL. Galactomannan test was performed on BAL and blood samples. Two days after the beginning of treatment with steroids and cotrimoxazole, the patient developed mild ARDS [4] that was initially treated with non-invasive mechanical ventilation (NIV) in the Intensive Care Unit (ICU). Later, ARDS evolved to the severe stage [4] and a significant pneumo-mediastinum with subcutaneous emphysema occurred. For this reason, eight days after the onset of respiratory failure, the patient was referred to the regional ECMO center.

Upon arrival at the referral ICU, the patient was intubated, tension pneumothorax was treated and veno-venous
ECMO was initiated (19 and $20 \mathrm{~F}$ cannulas were inserted into left and right femoral veins, respectively). The bypass was established with a blood flow of $3 \mathrm{~L} / \mathrm{min}$, corresponding to $60 \%$ of cardiac output and sweep gas of $5.5 \mathrm{~L} / \mathrm{min}$. This setting allowed a super-protective ventilatory strategy that consisted in a tidal volume of $5 \mathrm{ml} / \mathrm{kg}$ and a respiratory rate of 5 breaths $/ \mathrm{min}$ (Table 2). This strategy offered the advantage to rest the lung minimizing the risk of ventilator-induced lung injury [5]. At the third day of ECMO, the patient was successfully extubated and ventilated with non-invasive ventilation (NIV) by facemask. Details of HAART, antibiotic and antifungal treatments are shown in Table 1. After 20 days, ECMO was stopped when arterial blood gases were satisfactory for at least eight hours with a blood flow of $1.5 \mathrm{~L} / \mathrm{min}$ and a sweep gas of $0.5 \mathrm{~L} / \mathrm{min}$ (Table 3). After 10 days, the patient was discharged to a step down ICU and then at home. After 1 year of follow-up the plasma HIV-RNA was negative $(<20$ copies $/ \mathrm{ml})$ and the $T-C D 4+$ cell count was 90 cells/microL. 
Table 2 Ventilator settings before and after institution of ECMO

\begin{tabular}{|c|c|c|c|c|c|}
\hline & Before ECMO & & & & \\
\hline & VT $\left(\mathrm{ml} / \mathrm{kg}\right.$ PBW) or PIP $\left(\mathrm{cmH}_{2} \mathrm{O}\right)$ or SB & RR (breaths/min) & Pplat $\left(\mathrm{cmH}_{2} \mathrm{O}\right)$ & PEEP $\left(\mathrm{cmH}_{2} \mathrm{O}\right)$ & $\mathrm{PaO}_{2} / \mathrm{FiO}_{2}$ \\
\hline Patient 1 & VT 6 & 35 & 28 & 10 & 120 \\
\hline Patient 2 & $\mathrm{VT} 6$ & 30 & 29 & 16 & 90 \\
\hline Patient 3 & VT 6 & 25 & 28 & 16 & 100 \\
\hline & During ECMO & & & & \\
\hline Patient 1 & & & & & \\
\hline Day1 & PIP 20 & 5 & NA & 10 & 150 \\
\hline Day 3 & PSV / NIV 5 & 26 & NA & 8 & 200 \\
\hline Day 7 & SB & 28 & NA & NA & 180 \\
\hline Patient 2 & & & & & \\
\hline Day 1 & VT 5 & 5 & 27 & 16 & 120 \\
\hline Day 3 & VT 5 & 5 & 27 & 16 & 140 \\
\hline Day 7 & PSV 10 & 22 & NA & 10 & 160 \\
\hline Patient 3 & & & & & \\
\hline Day1 & VT 5 & 5 & 26 & 16 & 100 \\
\hline Day 3 & VT 5 & 5 & 26 & 16 & 90 \\
\hline Day 7 & VT 5 & 5 & 26 & 16 & 90 \\
\hline
\end{tabular}

The second patient was a 38 years old female (BMI $20.3 \mathrm{Kg} / \mathrm{m}^{2}$, PBW $52 \mathrm{Kg}$ ) that had a HIV-HCV infection treated with different HAART regimens, achieving virological suppression (negative plasma HIV-RNA) with T-CD4+ lymphocytes count of 200 cells/microL. After five days of flu-like respiratory symptoms and fever, the patient developed severe respiratory distress and was admitted to a peripheral hospital. Severe ARDS due to pneumonia caused by L. pneumophila (urinary antigens) was diagnosed. After two days, the patient was centralized to the ECMO center since refractory to conventional protective MV.

Table 3 Respiratory and ventilator variables before stopping ECMO

\begin{tabular}{|c|c|c|c|}
\hline & Patient 1 & Patient 2 & Patient 3 \\
\hline \multicolumn{4}{|l|}{ Main variables } \\
\hline $\mathrm{FiO}_{2}$ & 0.4 & 0.4 & 0.4 \\
\hline $\mathrm{PIP}(\mathrm{cmH} 2 \mathrm{O})$ & SB & 10 & 20 \\
\hline PEEP (cmH2O) & SB & 8 & 8 \\
\hline $\mathrm{PaO}_{2} / \mathrm{FiO}_{2}$ & 360 & 250 & 145 \\
\hline $\mathrm{PaCO}_{2}(\mathrm{mmHg})$ & 38 & 42 & 44 \\
\hline RR (breaths/min) & 22 & 21 & 26 \\
\hline
\end{tabular}

Additional variables

$\begin{array}{llll}C_{\text {RS }} & \text { NA } & 33 & 13\end{array}$

Values were obtained after 6-8 hours of sweep gas $0.5 \mathrm{~L} / \mathrm{min}$ and blood flow $1.5 \mathrm{~L} / \mathrm{min}$ with gas flow oxygen concentration 0.21 .

List of Abbreviations: VT (tidal volume), PIP (Peak inspiratory Pressure), SB (spontaneous breathing), RR (respiratory rate), Pplat (plateau pressure), PEEP (positive end expiratory pressure), $\mathrm{PaO}_{2} / \mathrm{FiO}_{2}$ (arterial pressure/inspired fraction of oxygen), $C_{R S}$ (Compliance of respiratory system).
A veno-venous ECMO (21 and $22 \mathrm{~F}$ cannulas were inserted into left and right femoral veins, respectively) was established, with a blood flow of $4 \mathrm{~L} / \mathrm{min}$ (equal to $70 \%$ of cardiac output) and sweep gas of $7 \mathrm{~L} / \mathrm{min}$ with $\mathrm{FiO}_{2}$ of $100 \%$ (Table 2). After six days of treatment, compliance of respiratory system $\left(28 \mathrm{ml} / \mathrm{cmH}_{2} \mathrm{O}\right) \mathrm{im}$ proved as a consequence of resolution of ARDS. Accordingly, the patient was shifted to assisted breathing and seven days later the patient was disconnected from the by-pass when arterial blood gases were satisfactory for at least eight hours with a blood flow of $1.5 \mathrm{~L} / \mathrm{min}$ and a sweep gas of $0.5 \mathrm{~L} / \mathrm{min}$, and the compliance of the respiratory system was $33 \mathrm{ml} / \mathrm{cmH}_{2} \mathrm{O}$ ) (Table 3). Details on HAART and antibiotic treatment are given in Table 1.

Eight days after centralization to the ECMO center, the patient developed signs of liver toxicity with jaundice (total bilirubin $28 \mathrm{mg} / \mathrm{dl}$ ), ascites and elevated liver enzymes (AST/ALT 185/50 UI/mL) requiring interruption of HAART; only levofloxacin monotherapy was continued. On day 22 the patient was transferred to the medical ward and after 6 months of follow-up, she was alive with a good immunovirological profile.

The third patient was a 24 years old male (BMI 23.5 $\mathrm{Kg} / \mathrm{m}^{2}, \mathrm{PBW} 61 \mathrm{Kg}$ ) that was admitted to a peripheral hospital with fever, cough and weight loss $(30 \mathrm{~kg}$ in the last three months). Chest CT scan showed diffuse and bilateral ground glass opacities and BAL was positive for $P$. jirovecii (PJP). Diagnosis of HIV infection was made and there were no plasma CD4+ lymphocytes detectable. Four days after the beginning of treatment with steroids and cotrimoxazole for PJP, the patient 
developed hypoxemic acute respiratory failure requiring invasive mechanical ventilation. Ten days after admission, the patient developed severe ARDS and he was centralized to the regional ECMO center. A veno-venous ECMO (21 and $22 \mathrm{~F}$ cannulas were inserted into left and right femoral veins, respectively) was established, with a blood flow of $3.5 \mathrm{~L} / \mathrm{min}$ and sweep gas of $6 \mathrm{~L} / \mathrm{min}$ with $\mathrm{FiO}_{2}$ of $100 \%$ (see Table 2). On the second day of ECMO, HAART was started and was associated with virological response but without immune recovery (after 1 month on HAART: HIV-RNA $600 \mathrm{cp} / \mathrm{ml} ; 3$ CD4+ lymphocytes/ microL). During the ICU stay, he also had a bloodstream infections by $K$. pneumoniae carbapenemase producing (KPC-Kp). Details on HAART and antibiotic treatment are given in Table 1. Full ECMO support remained unchanged for three weeks and it was discontinued only after 24 days when arterial blood gases were satisfactory for at least eight hours with a blood flow of $1.5 \mathrm{~L} / \mathrm{min}$ and a sweep gas of $0.5 \mathrm{~L} / \mathrm{min}$ (Table 3 ). However, the development of lung fibrosis, typically associated with the late phase of ARDS [6] left a severely impaired compliance of the respiratory system. On day 81 the patient was transferred to the ICU where he was initially admitted. After three months by the initial ICU admission the patient died for septic shock.

\section{Conclusion}

To the best of our knowledge, this is the first report on successful extracorporeal life support in patients with HIV infection. There are clinical and ethical considerations about ECMO support in patients with HIV infection and AIDS.

Evidence supporting ECMO as life saving treatment for adults with respiratory failure are growing $[1,2,7]$ However, ECMO is a costly intervention that may carry the risk of futility and serious side effects such as major bleeding and infection. Under these circumstances, indication and selection criteria need to be better defined, especially for the immune-compromised patients. In our reports, ECMO was used in severe, life threatening respiratory failure with etiological diagnosis and knowledge of the full potential of HAART, especially in the first patient who had discontinued treatment in the previous two years.

Extracorporeal Life Support Organization (ELSO) guidelines suggest ECMO when the risk for mortality is at least $50 \%$ (as identified by $\mathrm{PaO}_{2} / \mathrm{FiO}_{2}<150$ and or Murray score of 2-3) [8]. For immunocompromised patients, the guidelines do not propose absolute contraindications but suggest to consider the individual risks/benefits balance. Only leukopenia with absolute neutrophil count $<500 / \mathrm{mm}^{3}$ and recent or expanding central nervous system hemorrhages are considered relative contraindications. In patients with HIV infection, ECMO may erroneously be considered futile because of the patient's prognosis and of the uncertainties regarding the efficacy of HAART. Our reports show that ECMO is not futile when clinicians consider the immune-virological parameters with the full potential of HAART success.

In the first patient there were critical considerations, mainly represented by the concern for barotrauma after failure of NIV; there were HIV-related considerations such as the long history of HIV infection and HAART along with extensive multiclass drug resistance. However, in the last years the availability of new drugs and new classes of anti-retroviral allowed to achieve a high probability of virological success even in patients harboring multi-resistant virus [9]. Moreover, the individual level of compliance has been showed to be highly variable over a long history of HAART [10]. In our case, although a complex 6-drug based HAART was started, an adequate counseling after the discharge from ICU along with rapid clinical improvement reinforced patient's adherence, with treatment efficacy at 48-week.

L. pneumophila is the second most common cause of ICU admission amongst severe community acquired pneumonia (CAP) and PJP pneumonia is a frequent clinical presentation in antiretroviral-naïve patients [11]. Under these circumstances, the issue of ECMO in the last two patients may be more frequently encountered in daily practice. In particular, our second patient, in whom the ongoing HAART resulted in stable immunovirological parameters, may perhaps suggest the inclusion of ECMO into a treatment algorithm for HIV-positive patients undergoing HAART.

Special considerations are needed for the third patients where the futility of ECMO support was confuted by the excellent virological response to HAART, even if the absence of immune function recovery in the short term may not be easily predicted.

Predefined criteria to wean patients from ECMO are still lacking. In our center, satisfactory blood gases, obtained with sweep gas $0.5 \mathrm{~L} / \mathrm{min}$ and blood flow of $1.5 \mathrm{~L} / \mathrm{min}$ (gas flow oxygen concentration 0.21 ) for $6-8$ hours, is the main criteria. Moreover, the improvement of respiratory system compliance $(\mathrm{Crs}>30)$ is an additional criteria that we consider. In particular, we did not report the value of compliance of the first patient because she was breathing spontaneously when ECMO was stopped.

In conclusion, ECMO was effective in three HIVpositive patients with an otherwise fatal respiratory failure, even with severe immunosuppression or limited antiretroviral options. Two patients went back to their previous quality of life. Unfortunately, the third patient needed a prolonged ICU stay and did not have any recovery of immune function and died after three months by the hospital admission. This case series suggest that a 
multidisciplinary team, involving critical care and infectious diseases experts, is mandatory to define whether ECMO is an adequate therapeutic option also in immunocompromised patients, including those with HIV infection and AIDS.

\section{Consent}

The collection of data was approved by the local Ethical Committee regarding the use and collection of patients data within the ECMO support program, Città della Salute e della Scienza di Torino, Molinette S. Giovanni Battista Hospital, Turin, Italy. Written informed consent was obtained from the patients or next of kin for publication of these case reports. A copy of the written consent is available for review by the Editor of this journal.

\section{Abbreviations}

ECMO: Extracorporeal membrane oxygenation; MV: Mechanical ventilation; ARDS: Severe acute respiratory failure; HAART: Highly active antiretroviral treatment; PJP: Pneumocystis jirovecii pneumonia; NIV: Non-invasive mechanical ventilation; ICU: Intensive care unit; VILI: Ventilator induced lung injury;

CAP: Community acquired pneumonia.

\section{Competing interests}

The authors declare that they have no competing interests and no specific funding was received.

\section{Authors' contributions}

FDR, VF and VMR contributed to study design, data collection, drafting and writing the manuscript, including revision. SC contributed to data collection and drafting the manuscript. SB, GDP, RU, CB, DR and MR contributed to study design, supervision and critical revision of the manuscript for intellectual content. All authors read and approved the final manuscript. FDR and VF equally contributed to this work.

\section{Author details}

'Department of Medical Sciences, University of Turin, Infectious Diseases at Amedeo di Savoia Hospital, Corso Svizzera 164, 10149 Turin, Italy. ${ }^{2}$ Department of Surgical Sciences, University of Turin, City of Health and Science, Molinette Hospital, C.so Dogliotti 14, 10126 Turin, Italy. ${ }^{3}$ Department of Surgical Sciences, Cardiosurgery Unit, University of Turin, City of Health and Science, Molinette Hospital, C.so Dogliotti 14, 10126 Turin, Italy.

Received: 29 December 2013 Accepted: 6 May 2014

Published: 21 May 2014

\section{References}

1. Noah MA, Peek GJ, Finney SJ, Griffiths MJ, Harrison DA, Grieve R, Sadique MZ, Sekhon JS, McAuley DF, Firmin RK, Harvey C, Cordingley JJ, Price S, Vuylsteke A, Jenkins DP, Noble DW, Bloomfield R, Walsh TS, Perkins GD, Menon D, Taylor BL, Rowan KM: Referral to an extracorporeal membrane oxygenation center and mortality among patients with severe 2009 influenza $A(H 1 N 1)$. JAMA 2011, 306:1659-1668.

2. Patroniti N, Zangrillo A, Pappalardo F, Peris A, Cianchi G, Braschi A, lotti GA, Arcadipane A, Panarello G, Ranieri VM, Terragni P, Antonelli M, Gattinoni L, Oleari F, Pesenti A: The Italian ECMO network experience during the 2009 influenza $A(\mathrm{H} 1 \mathrm{~N} 1)$ pandemic: preparation for severe respiratory emergency outbreaks. Intensive Care Med 2011, 37:1447-1457.

3. Wachter RM, Luce JM, Safrin S, Berrios DC, Charlebois E, Scitovsky AA: Cost and outcome of intensive care for patients with AIDS, pneumocystis carinii pneumonia and severe respiratory failure. JAMA 1995, 273:230-235.

4. Ranieri VM, Rubenfeld GD, Thompson BT, Ferguson ND, Caldwell E, Fan E, Camporota L, Slutsky AS, ARDS Definition Task Force: Acute respiratory distress syndrome: the Berlin definition. JAMA 2012, 307:2526-2533.

5. Slutsky AS, Ranieri VM: Ventilator-induced lung injury. N Engl J of Med 2013, 369:2126-2136.
6. Ware LB, Matthay MA: The acute respiratory distress syndrome. N Engl J Med 2000, 342:1334-1349.

7. Pham T, Combes A, Rozé $\mathrm{H}$, Chevret $\mathrm{S}$, Mercat A, Roch A, Mourvillier B, Ara-Somohano C, Bastien O, Zogheib E, Clavel M, Constan A, Marie Richard JC, Brun-Buisson C, Brochard L, REVA Research Network: Extracorporeal membrane oxygenation for pandemic influenza $A(\mathrm{H} 1 \mathrm{~N} 1)$ induced acute respiratory distress syndrome: a cohort study and propensity-matched analysis. Am J Respir Crit Care Med 2013, 187:276-285.

8. Paden ML, Conrad SA, Rycus PT, Thiagarajan RR, ELSO Registry: Extracorporeal life support organization registry report 2012. ASAJO 2013, 59:202-210.

9. Simoni JM, Amico KR, Smith L, Nelson K: Antiretroviral adherence interventions: translating research findings to the real world clinic. Curr HIV/AIDS Rep 2010, 7:44-51.

10. El-Ebiary M, Sarmiento X, Torres A, Nogué S, Mesalles E, Bodí M, Almirall J: Prognostic factors of severe Legionella pneumonia requiring admission to ICU. Am J Respir Crit Care Med 1997, 156:1467-1472.

11. Gacouin A, Le Tulzo Y, Lavoue S, Camus C, Hoff J, Bassen R, Arvieux C, Heurtin C, Thomas R: Severe pneumonia due to Legionella pneumophila: prognostic factors, impact of delayed appropriate antimicrobial therapy. Intensive Care Med 2002, 28:686-691.

\section{doi:10.1186/1471-2253-14-37}

Cite this article as: De Rosa et al:: Extra Corporeal Membrane

Oxygenation (ECMO) in three HIV-positive patients with acute respiratory distress syndrome. BMC Anesthesiology 2014 14:37.

\section{Submit your next manuscript to BioMed Central and take full advantage of:}

- Convenient online submission

- Thorough peer review

- No space constraints or color figure charges

- Immediate publication on acceptance

- Inclusion in PubMed, CAS, Scopus and Google Scholar

- Research which is freely available for redistribution 